\title{
Neoplastic C-Cell Hyperplasia
}

National Cancer Institute

\section{Source}

National Cancer Institute. Neoplastic C-Cell Hyperplasia. NCI Thesaurus. Code C46101.

A neoplastic process arising from the C-cells of the thyroid gland. It is considered a precursor of hereditary medullary thyroid gland carcinoma, and it is associated with mutations of the RET gene. 